\title{
Late Paleozoic Structure of the Southern Part of the Uinta Basin, Utah, from Seismic Reflection Data
}

\section{U.S. GEOLOGICAL SURVEY BULLETIN $1787-\mathrm{V}$}

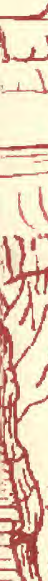

$\frac{15}{4}$

(1)

i)

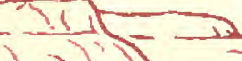

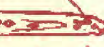

i)

$=-15$

(1) j)
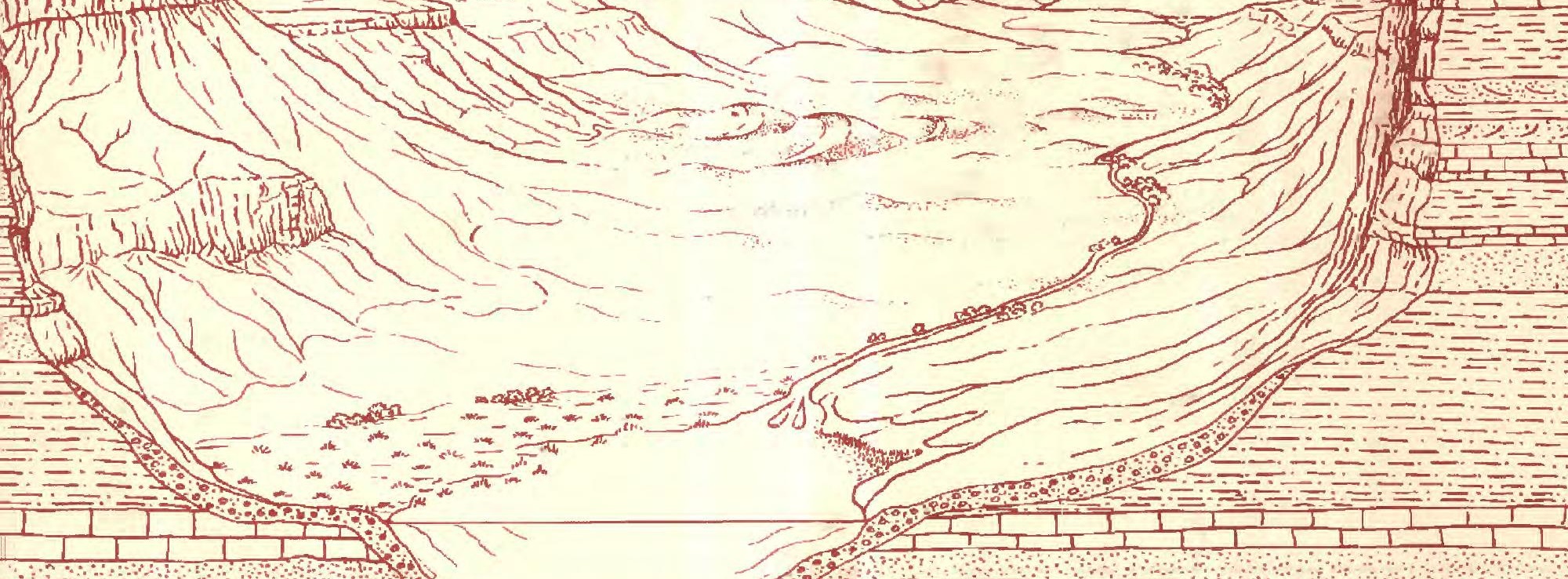

$E= \pm= \pm=$

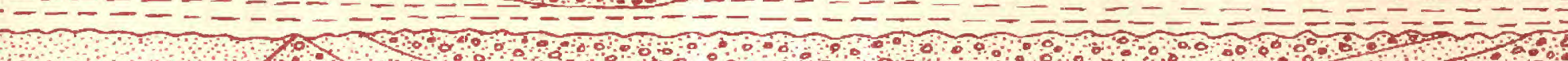

n 
Chapter V

Late Paleozoic Structure of the Southern Part of the Uinta Basin, Utah, from Seismic Reflection Data

BY CHRISTOPHER J. POTTER, REX TANG, and TIMOTHY J. HAINSWORTH

A multidisciplinary approach to research studies of sedimentary rocks and their constituents and the evolution of sedimentary basins, both ancient and modern

U.S. GEOLOGICAL SURVEY BULLETIN 1787

EVOLUTION OF SEDIMENTARY BASINS-UINTA AND PICEANCE BASINS 


\title{
U.S. DEPARTMENT OF THE INTERIOR
}

MANUEL LUJAN, JR., Secretary

\section{U.S. GEOLOGICAL SURVEY}

\author{
Dallas L. Peck, Director
}

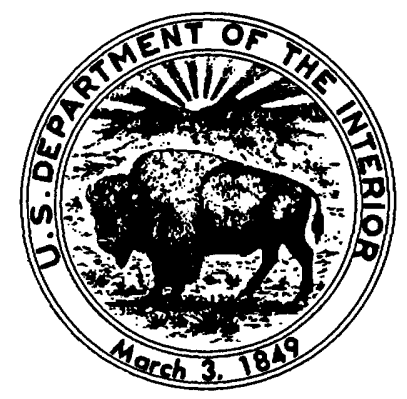

Any use of trade, product, or firm names in this publication is for descriptive purposes only and does not imply endorsement by the U. S. Government.

UNITED STATES GOVERNMENT PRINTING OFFICE: 1991

For sale by the

Books and Open-File Reports Section

U.S. Geological Survey

Federal Center, Box 25425

Denver, CO 80225

\section{Library of Congress Cataloging-in-Publication Data}

Potter, Christopher J.

Late Paleozoic structure of the southern part of the Uinta Basin, Utah, from seismic reflection data : a multidisciplinary approach to research studies of sedimentary rocks and their constituents and the evolution of sedimentary basins, both ancient and modern / by Christopher J. Potter, Rex Tang, and Timothy J. Hainsworth.

p. cm. -- (Evolution of sedimentary basins-Uinta and Piceance basins ; ch. V)

(U.S. Geological Survey bulletin ; 1787)

Includes bibliographical references (p. 10).

Supt. of Docs. no.: I 19.3:1787V

1. Geology, Stratigraphic-Paleozoic. 2. Sedimentary basins-Uinta Basin (Utah and Colo.) 3. Faults (Geology)-Uinta Basin (Utah and Colo.)

4. Geology-Uinta Basin (Utah and Colo.) 5. Seismic reflection

method. I. Tang, Rex. II. Hainsworth, Timothy J. III. Title. IV. Series.

V. Series: U.S. Geological Survey bulletin; 1787.

QE75.89 no. 1787-V

[QE654]

557.3 s--dc20

[551.7'2'09792]

$91-4303$ 


\section{CONTENTS}

Abstract V1

Introduction V1

Regional setting V3

Regional late Paleozoic stratigraphy; correlation with reflection data V3

Data V5

Structural patterns and thickness variations $\quad$ V7

Discussion V9

References cited V10

\section{PLATE}

[Plate is in pocket]

1. Seismic reflection lines in southern part of Uinta basin, Utah.

\section{FIGURES}

1, 2. Maps showing:

1. Regional geologic setting of study area, northeastern Utah $\mathbf{V 2}$

2. Late Paleozoic geologic setting of study area in southern part of Uinta basin V3

3. Chart showing upper Paleozoic stratigraphy of study area V4

4, 5. Maps showing:

4. Location of seismic reflection lines examined in study V4

5. Thickness variations for Doughnut Formation to Kaibab Limestone interval V5

6. Sketch showing seismic reflection patterns observed for late Paleozoic faulting in study area V6

7,8. Cross sections showing:

7. Variations in thickness of Doughnut Formation to Kaibab Limestone interval V6

8. Imbricate thrust structure east of Price $\quad$ V7

9. Map showing Paleozoic geologic setting of study area and major faults identified in study $\quad$ V8 


\title{
Late Paleozoic Structure of the Southern Part of the Uinta Basin, Utah, from Seismic Reflection Data
}

\author{
By Christopher J. Potter, Rex Tang1, and Timothy J. Hainsworth²
}

\section{Abstract}

Seismic reflection data from the southern part of the Uinta basin near Price, Utah, reveal a network of late Paleozoic faults that produced abrupt variations in stratigraphic thicknesses in a structurally complex $30-\mathrm{mi}(48 \mathrm{~km})$-wide northwest-southeast-trending trough. This zone is west of the ancestral Uncompahgre uplift, north of the Emery uplift, and east of the Oquirrh basin. In this zone, Pennsylvanian and Permian clastic rocks locally are several thousand feet thicker than in directly adjacent areas to the north and south.

Faults that displaced strata below the Kaibab Limestone but did not displace the Kaibab were active between Chesterian (top of Doughnut Formation) and Leonardian (Kaibab Limestone) time. High-angle reverse and normal faults occur in a block-faulting pattern similar to that observed in upper Paleozoic rocks in the Piceance basin in northwestern Colorado; thrust faults occur in a local north-south-trending belt. In localized zones of strong Mesozoic and (or) Cenozoic reactivation of the late Paleozoic faults, original fault styles are not clear.

West of Price, along the northern edge of the Emery uplift, the principal Paleozoic faults are northwest-striking, northeast-directed reverse faults that have as much as $5,000 \mathrm{ft}$ $(1,525 \mathrm{~m})$ of throw. This fault set is almost colinear with the Uncompahgre fault (which also underwent late Paleozoic reverse movement) but dips in the opposite direction. Pennsylvanian rocks are locally absent on reverse-fault-bounded structural highs. Steep northwest-striking normal faults are also present.

East and northeast of Price, west-directed thrust faults (and several east-directed backthrusts) controlled late Paleozoic deformation. High-angle reverse and normal faults are also present.

The major northwest-striking reverse faults and the westdirected thrusts accommodated displacements that are com-

Manuscript approved for publication March 29, 1991.

${ }^{1}$ The Louisiana Land and Exploration Company, 1 Civic Center Plaza, Denver, Colorado 80202.

2 P. O. Box 461841, Aurora, Colorado 80046. patible with late Paleozoic oblique sinistral-reverse slip on the Uncompahgre fault. The major reverse faults record a shortening direction parallel to that associated with the Uncompahgre fault. The west-directed thrust faults probably formed in response to the strike-slip component of movement of the Uncompahgre block as it moved west against the late Paleozoic basin. The probable genetic tie between the Uncompahgre fault and faults in the study area implies that the latter faults were most active during Desmoinesian time. Northwesttrending normal faults may record a relaxation of regional compressive stresses following Ancestral Rockies orogenesis. This interpretation relates all of these late Paleozoic faults to Ancestral Rockies tectonism. Most of the late Paleozoic faults in the study area have undergone only minor post-Paleozoic reactivation or deformation, although major Mesozoic and Cenozoic reactivation locally has occurred.

\section{INTRODUCTION}

Regional unconformities and thick sedimentary basins in the central Rocky Mountains, Colorado Plateau, and northeastern part of the Great Basin preserve an impressive record of late Paleozoic ("Ancestral Rockies") orogenesis, but many regional structures of this age have been obscured by younger tectonism, basin development, and volcanism. With few exceptions, major late Paleozoic faults at the margins of Precambrian exposures have been reactivated or overprinted by Laramide-age (Late Cretaceous to Eocene) or younger faults. In order to understand late Paleozoic faulting, it is necessary to separate younger movement from Paleozoic movement or to identify unreactivated Paleozoic structures. Identification of late Paleozoic faults that have not been reactivated (or have undergone only minor reactivation) is best accomplished using subsurface (well and seismic) data (for example, Frahme and Vaughn, 1983). In this study, seismic reflection data from the southern part of the Uinta basin, near Price, Utah, are used to illustrate the style of late Paleozoic deformation northwest of the ancestral Uncompahgre uplift. 


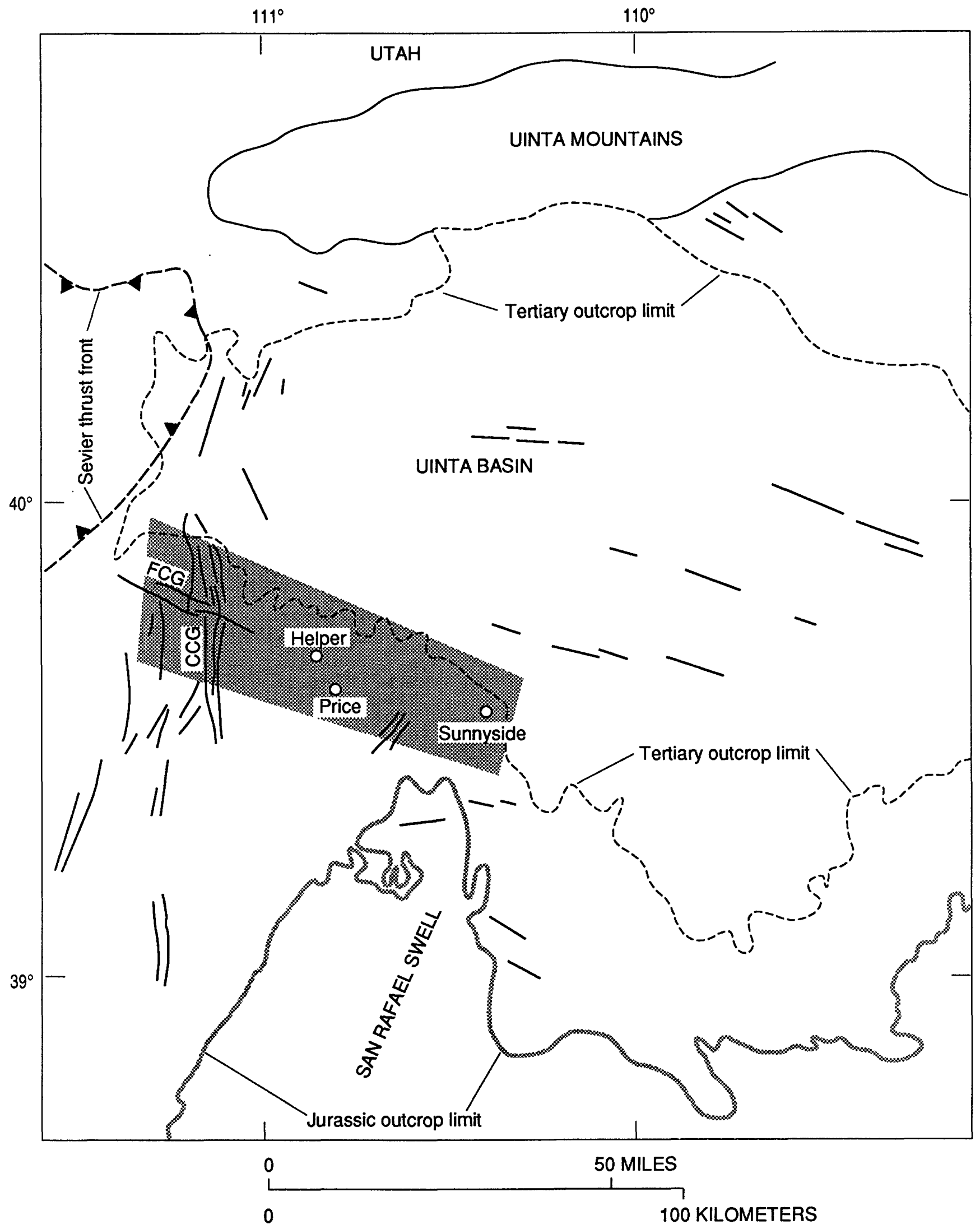

Figure 1. Regional geologic setting of the study area (screened pattern), northeastern Utah. CCG, Clear Creek graben; FCG, Fish Creek graben. 
Acknowledgment.-We thank Grant Norpac, Inc., for permission to publish seismic reflection sections EU-1-85, EU-5, EU-6, and EU-9.

\section{REGIONAL SETTING}

The study area (fig. 1) is on the south flank of the Laramide-age Uinta basin, directly north of the San Rafael swell. Tertiary faults (for example, the Clear Creek and Fish Creek grabens; Osmond, 1965), as well as numerous late Paleozoic fault blocks and small basins that can be defined on seismic reflection data (this report), are present in the area. The Paleozoic basins and faults accommodated displacements in a zone bounded by four major late Paleozoic geologic features: the ancestral Uncompahgre uplift, the Emery uplift, the Paradox basin, and the Oquirrh basin (fig. 2). Buried late Paleozoic faults have also been identified in seismic data from the Piceance basin of northwestern Colorado, northeast of the Uncompahgre uplift (Waechter and Johnson, 1985), and the San Juan Basin of northwestern New Mexico (Huffman and Taylor, 1989). The style and regional significance of buried late Paleozoic structures in the study area are examined in this report.

The late Paleozoic faults that bound the ancestral Uncompahgre uplift (fig. 2) can be traced into the study area in the subsurface (Stone, 1977). The Uncompahgre fault, on the southwest side of the uplift, underwent southwestdirected reverse motion in late Paleozoic time (Frahme and Vaughn, 1983; White and Jacobsen, 1983). Stone (1977) inferred that there was also a significant left-lateral component to late Paleozoic displacement on the Uncompahgre fault, whereas Stevenson and Baars (1986) argued for rightlateral motion. The Garmesa fault forms the northeast

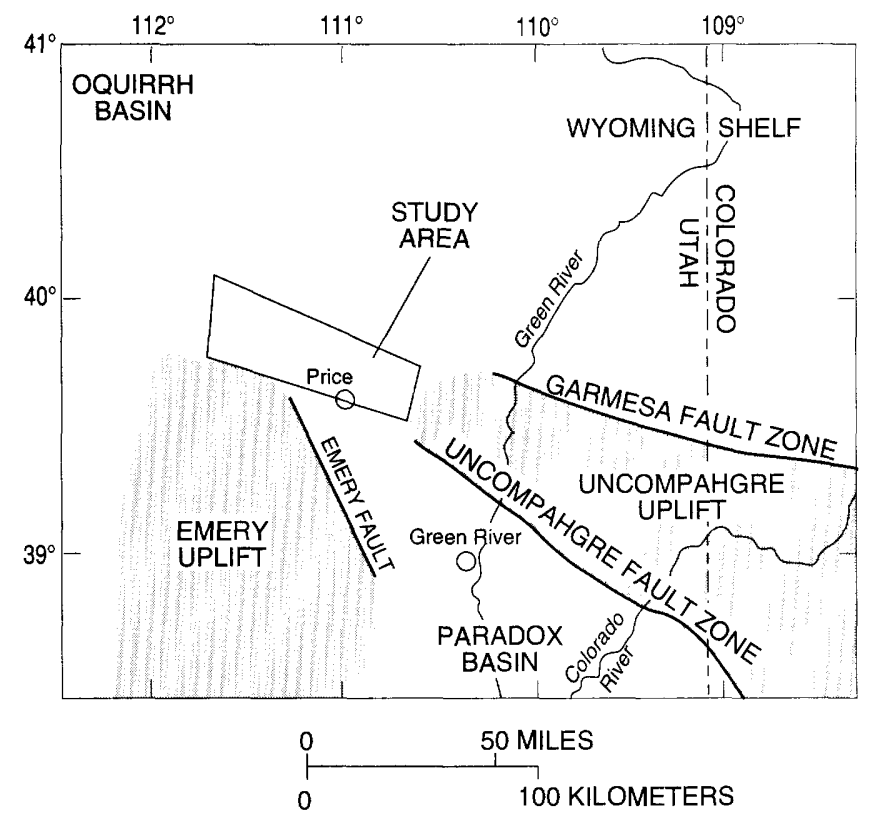

Figure 2. Late Paleozoic geologic setting of the study area in the southern part of the Uinta basin, Utah. boundary of the uplift. It underwent much less displacement than the Uncompahgre fault; movement was oblique, dominated by left-lateral slip (Stone, 1977). Late Paleozoic displacements on these faults diminished to zero within, or just east of, the study area, where displacements were accommodated along a system of intersecting shorter faults. Laramide reactivation occurred along the Garmesa fault, east of the study area (Osmond, 1965), but apparently did not occur along the northwestern part of the Uncompahgre fault (Heyman, 1983).

Szabo and Wengerd (1975) documented a subsurface late Paleozoic fold and fault belt striking N. $60^{\circ} \mathrm{W}$. beneath the Paradox basin adjacent to the south flank of Uncompahgre uplift. The northwestern end of this belt merges into the "Price graben" of Szabo and Wengerd (1975) between Green River and Price. The "Price graben" formed in late Paleozoic time and is bounded on the northeast by the Uncompahgre fault and on the southwest by the Emery fault (fig. 2) (Szabo and Wengerd, 1975); part of it occupies the southeastern part of the study area. The present study indicates that it is not a true graben and that the late Paleozoic structure of the Price area is more complex than that portrayed by Szabo and Wengerd (1975).

Hite (1975) documented a northeast-striking fault set in the Paradox basin and presented evidence for left-lateral displacement along these faults. Some of this displacement is clearly Jurassic or younger, but the earlier history of this fault set is poorly understood (Hite, 1975).

Southwest of Price, the Emery fault, oriented approximately N. $30^{\circ} \mathrm{W}$., forms the northeastern boundary of the late Paleozoic Emery uplift (Szabo and Wengerd, 1975) (fig. 2). Several N. $60^{\circ} \mathrm{W}$.-trending faults developed within the Emery uplift, oblique to the Emery fault (Szabo and Wengerd, 1975).

The San Rafael swell (fig. 1) developed during the Laramide across the grain of the Emery uplift. Laramide deformation is responsible for the present northerly regional dip in the study area, which is at the north-plunging end of the San Rafael swell and on the north-dipping south flank of the Uinta basin. Younger fault zones are prominent in the western part of the study area on the Wasatch Plateau. These include the north-trending Clear Creek graben and the northwest-trending Fish Creek graben (Osmond, 1965) (fig. 1). The seismic data examined in this study demonstrate that the Fish Creek graben reactivated late Paleozoic faults.

\section{Regional Late Paleozoic Stratigraphy; Correlation With Reflection Data}

A stratigraphic column for the upper Paleozoic rocks of the study area is shown in figure 3. These strata are penetrated by deep wells at several locations, and key reflections from this interval can be traced on seismic reflection lines that can be tied to these wells (fig. 4). Identifications of key stratigraphic horizons were calibrated using sonic logs and velocity surveys in the wells.

The deepest Paleozoic reflector generally recognized in the area is the top of the Mississippian carbonate rocks 


\begin{tabular}{|c|c|}
\hline \multirow{4}{*}{ 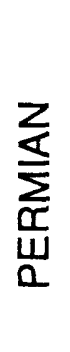 } & OCHOAN \\
\hline & GUADALUPIAN \\
\hline & LEONARDIAN \\
\hline & WOLFCAMPIAN \\
\hline \multirow{4}{*}{ 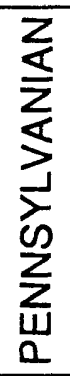 } & VIRGILIAN \\
\hline & MISSOURIAN \\
\hline & $\overbrace{\text { ATOKAN }}^{\text {DESMOINESIAN }}$ \\
\hline & MORROWAN \\
\hline \multirow{4}{*}{ 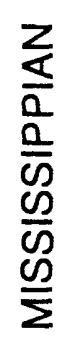 } & CHESTERIAN \\
\hline & MERAMECIAN \\
\hline & OSAGEAN \\
\hline & KINDERHOOKIAN \\
\hline
\end{tabular}

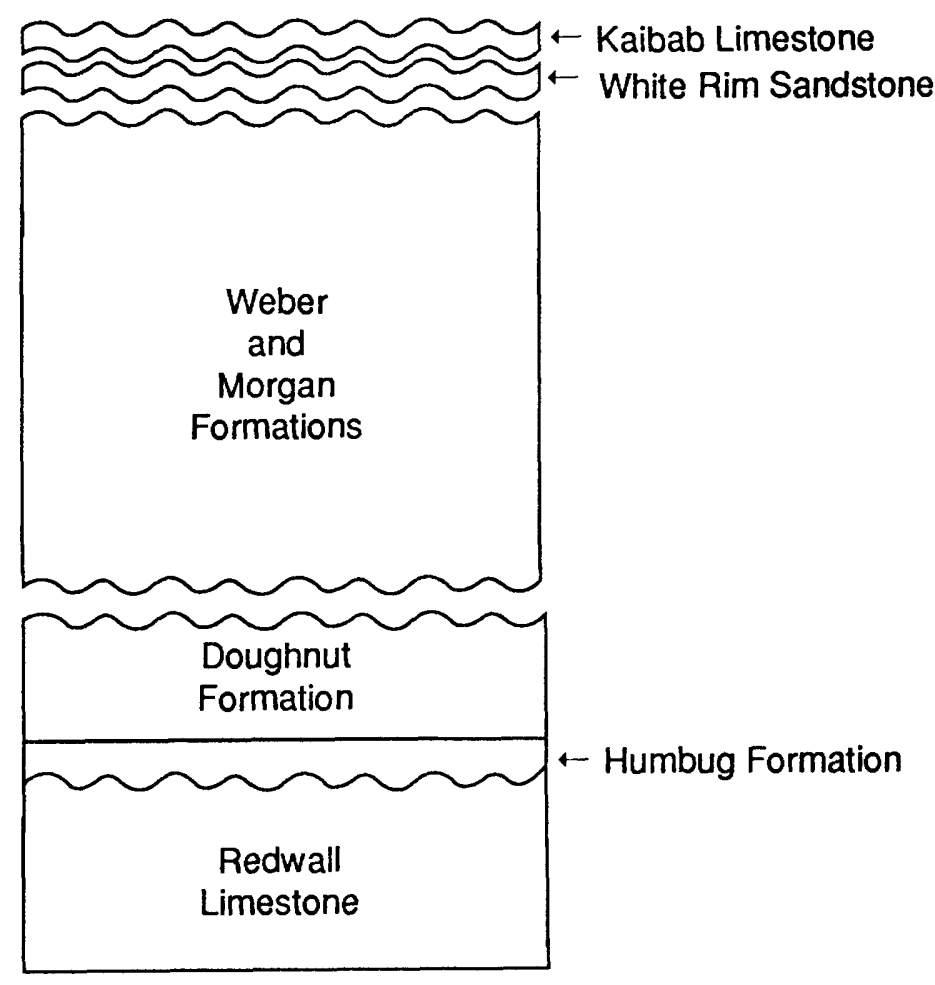

Figure 3. Upper Paleozoic stratigraphy of the study area in the southern part of the Uinta basin, Utah.

correlative with the Redwall and Leadville Limestones. Franczyk (in press) uses the term Madison Limestone in the area north of the Emery uplift, and the name Deseret Limestone is commonly used in industry logs of well and seismic data in the vicinity of Price. These rocks will be called Redwall in this report, following Hintze (1988). On the seismic lines examined in this study, the Redwall reflection (lines EU-5 and EU-9, plate 1) is a doublet that cannot be traced entirely across any of the seismic lines, probably because of signal penetration problems. The relatively unreflective interval above the Redwall represents the Humbug Formation and the Doughnut Formation (commonly referred to as the Manning Canyon Shale on well logs in the study area). A well-defined doublet at the base of an overlying set of banded reflections (lines EU-5 and EU-9, plate 1) marks the top of the Doughnut. The banded reflection sequence corresponds to mixed clastic and carbonate rocks of the Pennsylvanian and Permian "undifferentiated Weber and Morgan Formations" (Franczyk, in press). A prominent reflection from the Kaibab Limestone (of Leonardian and locally Guadalupian age; Hintze, 1988) lies above the Weber and Morgan reflections.

In this study, local thickness variations are documented in the interval between the Doughnut and Kaibab reflections

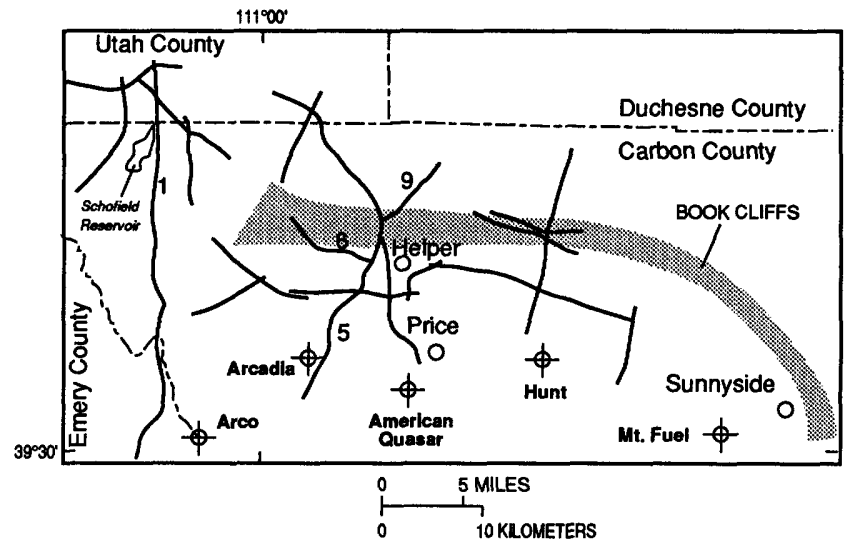

Figure 4. Location of seismic reflection lines examined in this study (heavy lines) and deep wells that penetrate the upper Paleozoic section. Numbered lines $(1,5,6,9)$ refer to GrantNorpac seismic lines EU-1-85, EU-5, EU-6, and EU-9, which are shown on plate 1. Wells: Arco, Arco Hiawatha no. 1; Arcadia, Arcadia Telonis no. 1; American Quasar, American Quasar 31-1 Drunkards Wash; Hunt, Hunt 1-16 State; Mt. Fuel, Mountain Fuel no. 1 Sunnyside. 

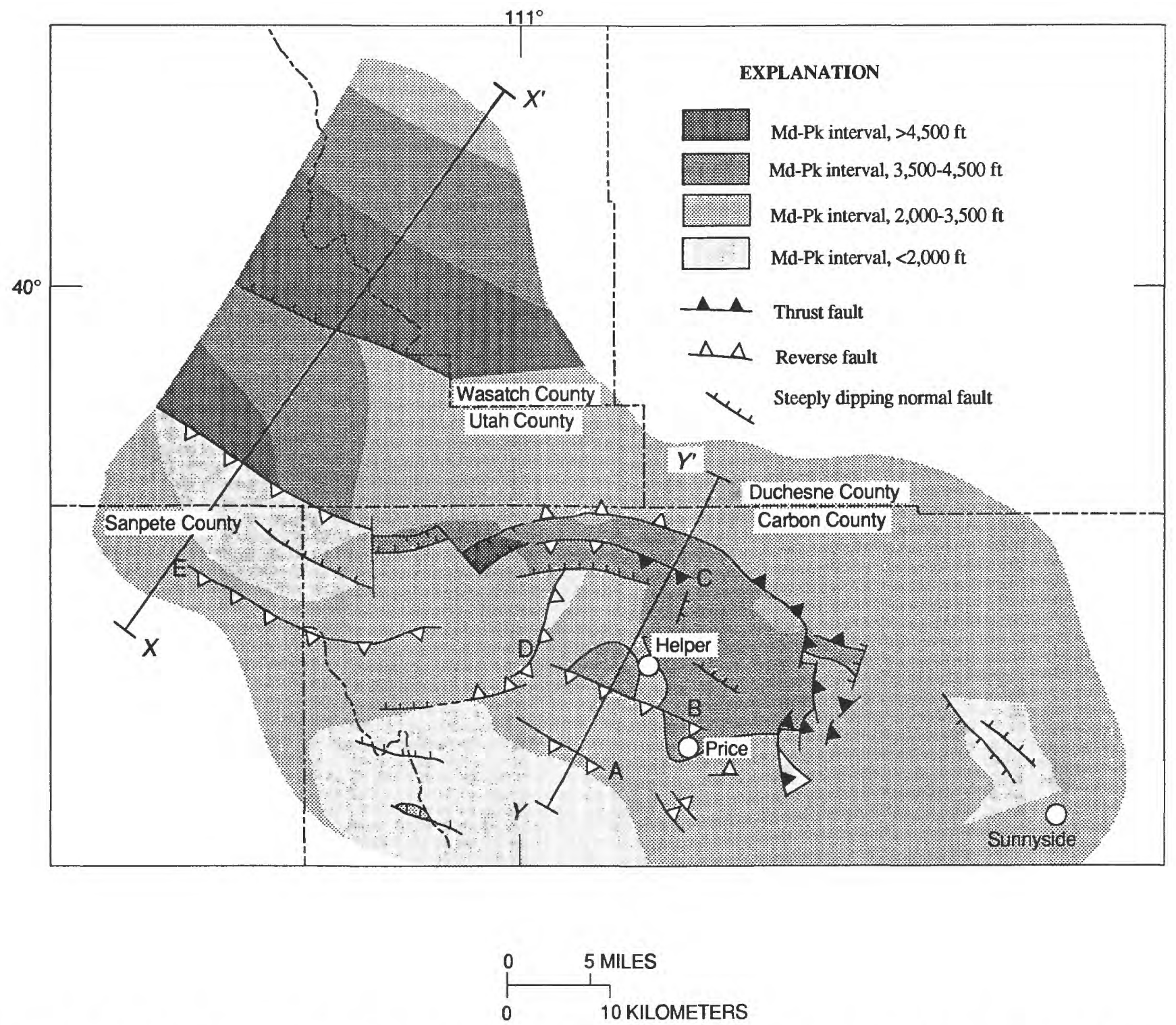

Figure 5. Thickness variations for the Doughnut Formation (Md) to Kaibab Limestone (Pk) interval; faults identified or inferred based on the reflection data are shown. Lines of sections $X-X^{\prime}$ and $Y_{-} Y^{\prime}$ (fig. 7) are also shown. A, B, C, D, and E are faults shown on plate 1 and discussed in text.

(fig. 5). This interval is occupied mainly by the Weber and Morgan Formations. In many cases, the thickness of the Weber and Morgan abruptly changes across Pennsylvanian or Permian faults. On seismic sections, these faults displace Mississippian reflections but do not displace the Kaibab reflection (lines EU-5 and EU-9, plate 1, fig. 6). They are the primary evidence used to interpret the late Paleozoic structural evolution of the region and are mapped in the subsurface in this study (fig. 5). On some seismic sections, a "Pl" (for lower Permian) reflection is identified within the Pennsylvanian and Permian section (fig. 6). This reflection is tentatively correlated with the top of an interbedded marine limestone, sandstone, and shale unit of Virgilian and Wolfcampian age (lower Cutler beds of Loope and others, 1990; includes rocks assigned to Elephant Canyon Forma- tion by Baars, 1962). Similar to the Kaibab, the Pl reflection is not typically cut by late Paleozoic faults.

\section{DATA}

An extensive network of intersecting seismic lines was examined in this study; locations of selected seismic lines are shown in figure 4. Sonic logs and velocity surveys in wells along the seismic lines were used to verify the correlation between reflections and the stratigraphic section. Two-way travel times for the Doughnut to Kaibab interval were measured along these lines, and these travel times were converted to the thicknesses shown on figure 5. This 
TYPICAL SEISMIC REFLECTION PATTERNS

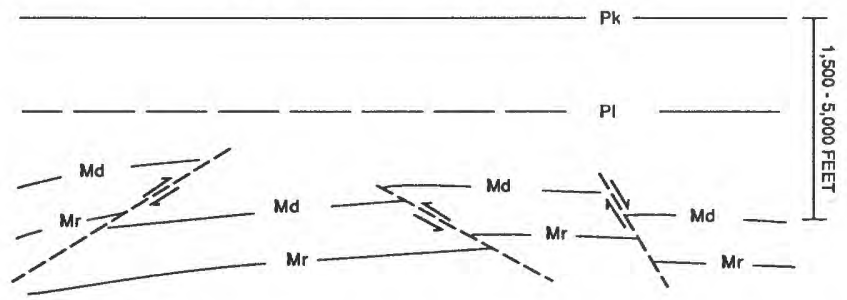

Figure 6. Seismic reflection patterns observed for late Paleozoic faulting in the study area. The subhorizontal solid and dashed lines are schematic representations of reflections. In this idealized diagram, Mississippian reflectors are offset by the faults and Permian reflectors are not. Examples of actual data (plate 1) demonstrate that in some cases Permian and Mesozoic reflectors have been gently folded above Paleozoic faults by minor Laramide reactivation of the faults. Pk, Kaibab Limestone; PI, top of Upper Pennsylvanian-Lower Permian interbedded limestone, shale, and sandstone sequence; $\mathrm{Md}$, Doughnut Formation; Mr, Redwall Limestone.

conversion was calibrated using several deep wells (Hunt 1-16 State, American Quasar 31-1 Drunkards Wash, Arcadia Telonis no. 1) that penetrate upper Paleozoic rocks near the reflection lines (fig. 4). Because the average seismic velocity for this stratigraphic interval differs in each of these wells and would certainly vary throughout the study area, thickness values are approximate.

Fault geometry and sense of offset along late Paleozoic faults were determined based on identification of hangingwall and footwall cutoffs of Mississippian reflections. Faults illustrated on figure 5 were identified on more than one seismic line in almost every case. Identification of several of the faults on three or more seismic lines permitted detailed observation of along-strike variations in offset and fault geometry.
Seismic data that illustrate the structural styles are shown on plate 1. These Vibroseis data (lines EU-1-85, EU-5, EU-6, and EU-9) were recorded by Grant Norpac, Inc., in July 1983 (EU-5), June 1984 (EU-6, EU-9), and June 1985 (EU-1). Lines EU-5, EU-6, and EU-9 were acquired using a 16-second, $14-80-\mathrm{Hz}$ source sweep, a shot point interval of $440 \mathrm{ft}$ (134 m), 96 geophone groups with $220-\mathrm{ft}(67 \mathrm{~m})$ spacing, and a nominal stacking fold of 24 . Line EU-1 was acquired using a 16-second, $10-56-\mathrm{Hz}$ source sweep, a shot point interval of $330 \mathrm{ft}(101 \mathrm{~m}), 120$ geophone groups with $165-\mathrm{ft}(50 \mathrm{~m})$ spacing, and a nominal stacking fold of 30 .

Seismic lines EU-5 and EU-9 form a 17-mi (27 km)long northeast-southwest transect in the vicinity of Helper (plate 1). Along these seismic lines, the Doughnut to Kaibab interval gradually thickens from southwest to northeast from approximately 1,500 to $3,600 \mathrm{ft}(457-1,097 \mathrm{~m})$ and three northeast-directed reverse and thrust faults $(A, B, C)$ intersect the lines. The geometry of each of these faults is constrained by hanging-wall and footwall cutoffs of Mississippian reflectors (Redwall and Doughnut). Based on these relationships, faults $A, B$, and $C$ dip approximately $30^{\circ}$, $50^{\circ}$, and $10^{\circ} \mathrm{SE}$, respectively. Updip from fault $A$, a local increase in dip in the Mesozoic reflectors indicates minor Laramide (?) reactivation of this fault.

Local discordances (truncation or onlap) within the Pennsylvanian and Permian banded zone attest to uplift of individual fault blocks. Near the Arcadia Telonis no. 1 well (line EU-5, plate 1), inclined reflections in the banded Pennsylvanian and Permian sequence in the hanging wall of fault $A$ are locally truncated. The Pl reflection appears to be folded above, and perhaps offset by, fault A. A dipping reflection in the interval between the $\mathrm{Pl}$ and $\mathrm{Pk}$ reflections (fig. 5) is truncated and overlain by subhorizontal reflections. To the north, the $\mathrm{Pl}$ reflection continues undeformed above faults $\mathrm{B}$ and $C$. Just south of fault $C$, there is a southward-onlapping pattern at a lower stratigraphic level within the banded Pennsylvanian and Permian reflections. Thus, within these two

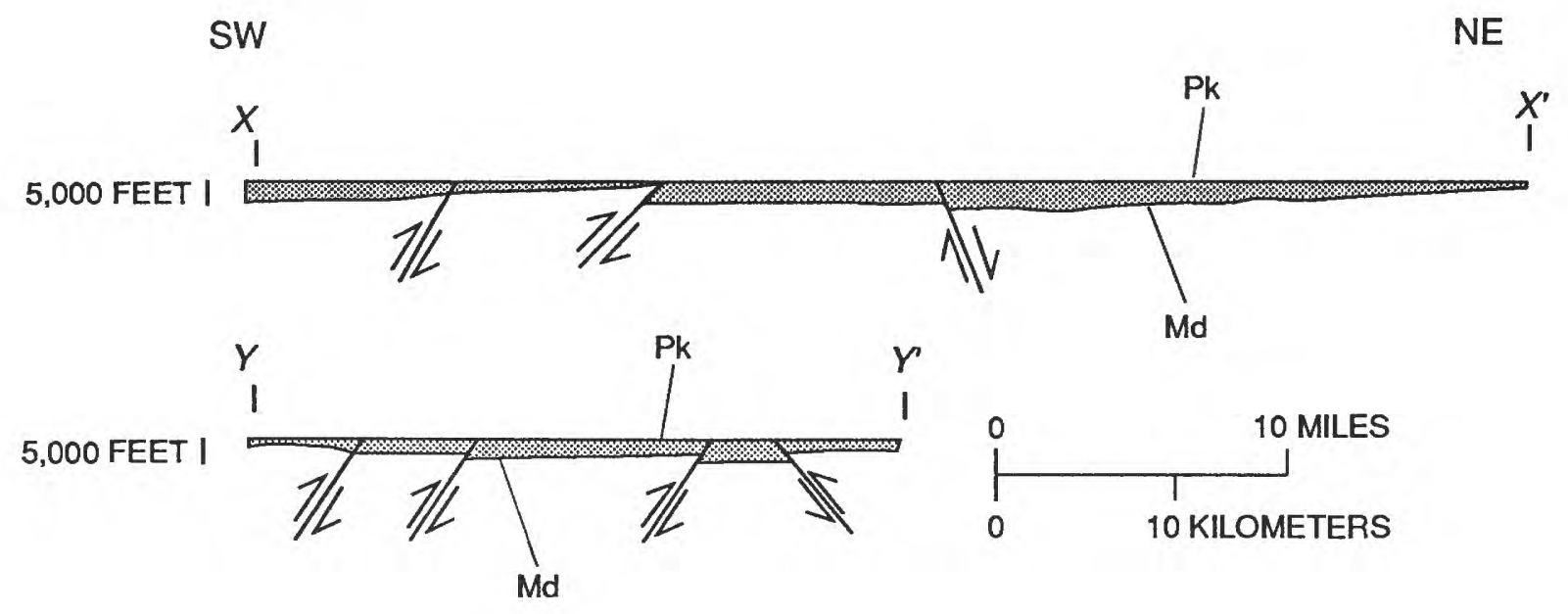

Figure 7. Cross sections $X-X^{\prime}$ and $Y-Y^{\prime}$ showing variations in thickness in the Doughnut Formation (Md) to Kaibab Limestone (Pk) interval, and traces of major faults. Datum is top of Kaibab Limestone; no vertical exaggeration. Shaded area is the Md-Pk interval. Lines of sections are shown in figure 5. 
seismic lines, several local unconformities provide evidence for localized erosion and (or) nondeposition at slightly different stratigraphic positions.

Line EU-6 (plate 1), which extends to the northwest from the intersection of lines EU-5 and EU-9 near Helper (fig. 4), illustrates gradual northwesterly thinning of the Doughnut to Kaibab interval on the upthrown (southeast) side of a minor steeply dipping fault (D). The fault geometry is not well constrained by the seismic data here, and the dip of Doughnut reflections away from the fault in both directions suggests that an arch is locally developed. Southeast of the fault, a local angular unconformity is defined by the onlapping of Pennsylvanian and Permian strata above the gently southeast dipping Doughnut reflector. It is possible that fault-induced arching produced a submarine, or barely emergent, topographic high across which younger layers onlapped. Arching of reflectors above fault $D$ in the Kaibab through Dakota section demonstrates that post-Paleozoic deformation persisted in this zone and probably included Laramide reactivation of the fault.

Line EU-1 (plate 1) is a 26-mi (42 km)-long, north-south seismic line in the western part of the study area. Data quality on line EU-1 is inferior to that of the other seismic lines discussed here, especially in an 8-mi $(13-\mathrm{km})$ interval (denoted by shading along the top of the line drawing in plate 1) near Schofield Reservoir (fig. 4). The poorer data quality may be related to raypath complexities produced by young structures; line EU-1 follows the Clear Creek graben, and the Fish Creek graben crosses the seismic line near Schofield Reservoir (Osmond, 1965). The data quality deteriorates significantly in the Fish Creek graben, and the graben itself is not well imaged. The Mesozoic or younger faults that are apparent on plate 1 may be related to the Clear Creek graben; the seismic line is highly oblique to the strike of this northtrending fault zone.
Although the Paleozoic section is not well imaged on line EU-1, some significant trends are apparent. The southern part of the line is on the north flank of the Emery uplift, as evidenced by the absence of the Doughnut Formation along the southern one-third of this line and in the nearby Arco Hiawatha no. 1 well. North of fault E, the Redwall to Kaibab interval abruptly thickens and discontinuous Doughnut reflections may be present (plate 1). In the northern part of the line EU-1, there are obvious Doughnut reflections. The abrupt variation in thickness of the late Paleozoic section across fault $E$ indicates that the fault was active during late Paleozoic time. Other faults on this seismic line may have undergone Paleozoic movement, but all of these faults also underwent younger movement, as shown by the offset of the Kaibab and younger reflectors. Thus, it is difficult to obtain a clear picture of late Paleozoic movement for these faults.

\section{STRUCTURAL PATTERNS AND THICKNESS VARIATIONS}

The overall pattern of faults and thickness variations is shown on figure 5. In most of the study area, the thickness of the Doughnut to Kaibab interval varies from about 1,500 to about $4,500 \mathrm{ft}(457-1,372 \mathrm{~m})$; the variation is principally controlled by local syndepositional faulting. The interval is thinnest (1) west and southwest of Helper, corresponding to the north flank of the Emery uplift, and (2) around Sunnyside, at the northwest end of the ancestral Uncompahgre uplift (fig. 5).

West of Price, the principal Paleozoic faults are northwest-striking, northeast-directed reverse faults that step off of the northern and northeastern margins of the Emery uplift and have as much as $5,000 \mathrm{ft}(1,525 \mathrm{~m})$ of throw (figs.
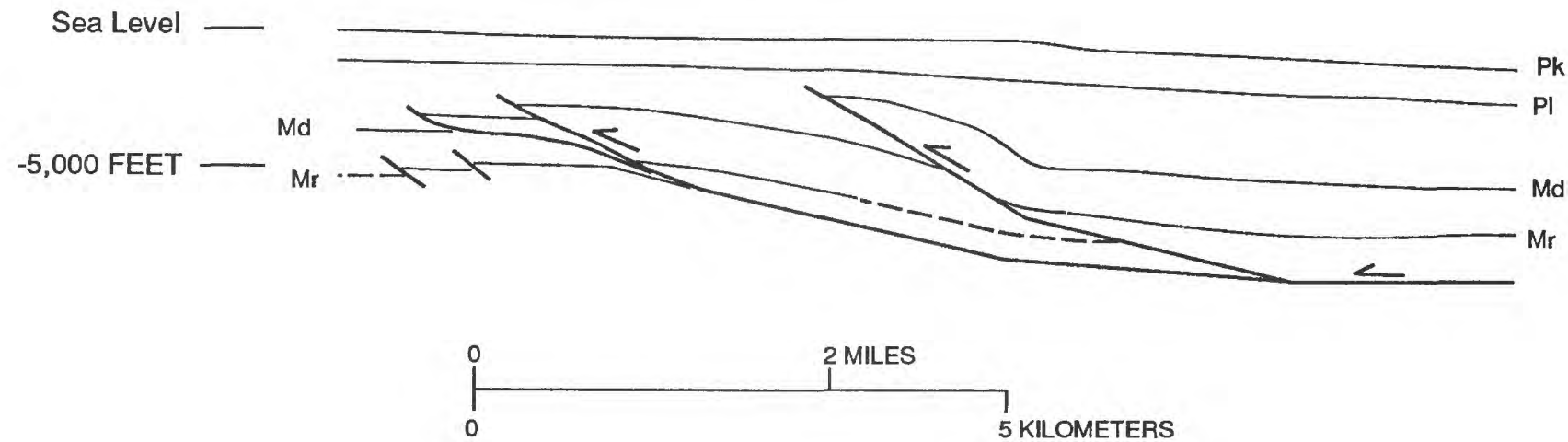

Figure 8. Cross section interpreted from a migrated seismic section about $6 \mathrm{mi}(10 \mathrm{~km})$ east of Price, illustrating imbricate thrust structure that is part of a small north-south-trending thrust system. Thrust faults shown here have produced about 1.2 mi $(2.0 \mathrm{~km})$ of shortening. Solid lines are traced from reflections, dashed lines are interpreted continuations of stratigraphic horizons, and stippled lines are inferred faults. Vertical exaggeration approximately 0.85 . Stratigraphic symbols denote top of unit as inferred from seismic data. Pk, Kaibab Limestone; Pl, top of Upper Pennsylvanian-Lower Permian interbedded limestone, shale, and sandstone sequence; Md, Doughnut Formation; Mr, Redwall Limestone. 


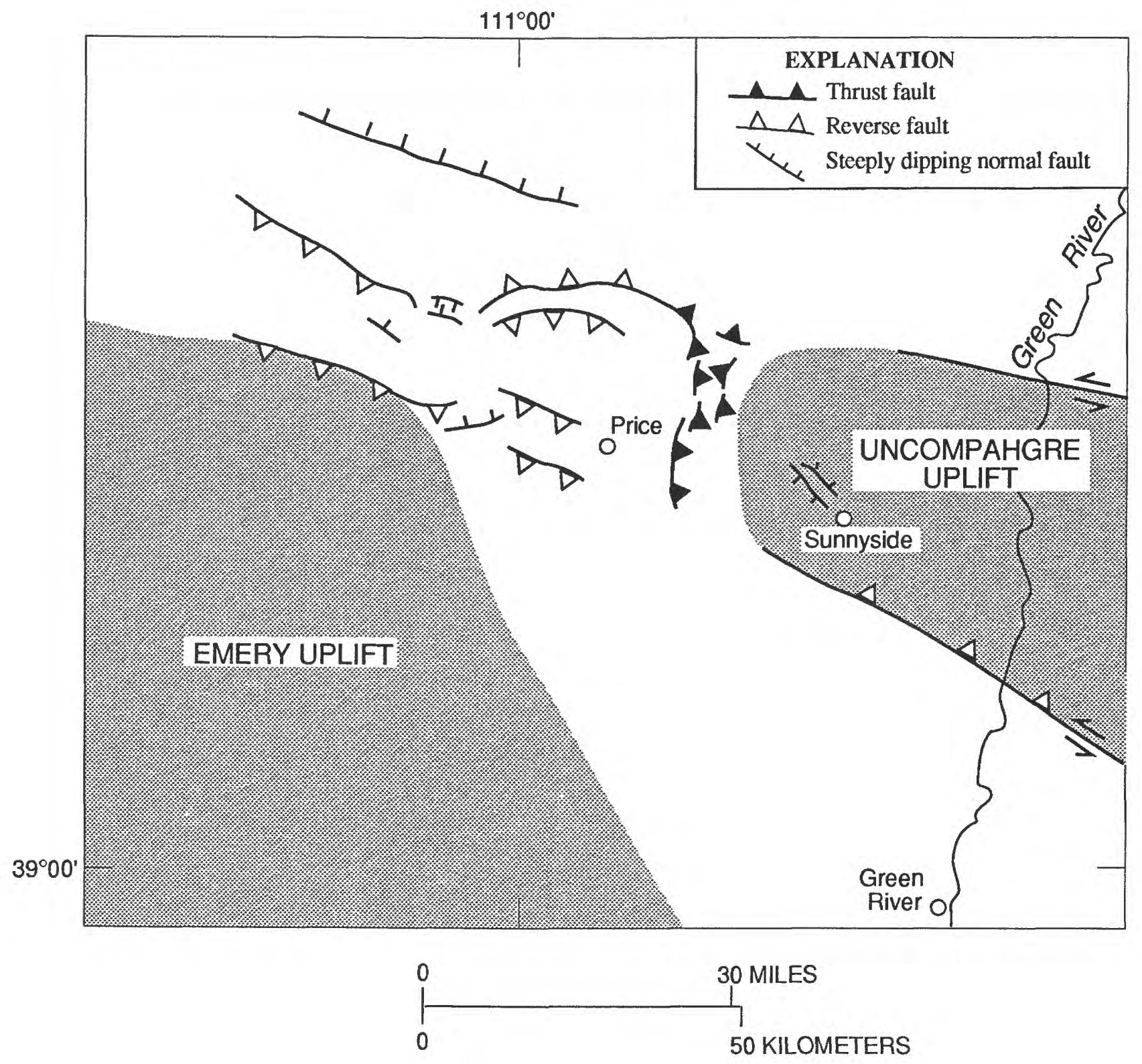

Figure 9. Paleozoic geologic setting of the study area including major faults identified in this study.

5,7). Across one of these faults, the preserved thickness of the Doughnut to Kaibab interval varies from zero (where the entire interval has been locally eroded) to more than $5,000 \mathrm{ft}$ $(1,525 \mathrm{~m})$. Steep northwest-striking normal faults are also present.

North of Helper, a thickened late Paleozoic section in an east-west-striking subbasin occupies a footwall position with respect to two bounding reverse faults that have opposing displacement directions (figs. 5, 7). The more northerly of the two reverse faults merges to the southeast with a northerly striking, west-directed thrust system that controlled late Paleozoic deformation east and northeast of Price.

The structural style in this thrust system resembles that of a foreland thrust belt, in contrast to the block-faulting style that is evident to the west. Figure 8 illustrates imbricate thrust structure observed on a seismic line about $6 \mathrm{mi}$ (10 $\mathrm{km}$ ) east of Price. A few backthrusts as well as high-angle reverse and normal faults are also present (fig. 5).

The reflection patterns indicate that many of the late Paleozoic faults in this region are essentially growth faults, regardless of geometry (normal, thrust, or reverse). Although local truncation and onlapping relationships within the Morgan and Weber Formations are indicative of local emergence of fault blocks, most of the faulting probably occurred in a relatively shallow submarine setting during Pennsylvanian and Permian deposition and did not result in widespread subaerial exposures.

Mesozoic and Tertiary reactivation and overprinting are most apparent near the Clear Creek and Fish Creek grabens and near Sunnyside (fig. 1). Young faulting occurred in 
other parts of the study area, but in most cases the late Paleozoic structures have not been greatly modified by younger faulting.

\section{DISCUSSION}

Fault patterns in the study area present a complex picture dominated by high-angle (block) faulting in the western part of the study area and by thrust faulting in the eastern part. Reverse and thrust faulting are predominant, but normal faults are locally important.

A distinctive style of faulting is associated with each of the two Ancestral Rockies uplifts that bound the study area. Northwest-striking, steeply southwest-dipping reverse faults bound the Emery uplift on its northern and northeastern sides, whereas a north-striking, west-directed local thrust system bounds the ancestral Uncompahgre uplift at its northwest end. The other faults may comprise an interference pattern between these two principal zones, as will be discussed later in this section.

The northwesterly strike of reverse faults that step off the north end of the Emery uplift is almost parallel to the strike of the Uncompahgre fault, known to be a major late Paleozoic reverse fault (fig. 9). The faults are also parallel to the N. $60^{\circ} \mathrm{W}$.-striking faults documented by Szabo and Wengerd (1975) within the Emery uplift. Although the Uncompahgre fault dips northeast and the faults north of the Emery uplift dip southwest, the orientation of all of these faults is compatible with regional northeast-southwest shortening.

West-directed thrusting at the northwest end of the Uncompahgre uplift requires that the Uncompahgre block moved west with respect to the late Paleozoic sedimentary basin in the study area. Such movement agrees with Stone's (1977) conclusion that the Uncompahgre fault experienced significant strike-slip motion in addition to its welldocumented reverse slip (Frahme and Vaughn, 1983). Several miles of left-lateral motion on the Uncompahgre fault could have been transferred to the west-directed thrust system, in which shortening occurred in front of the westdriven Uncompahgre uplift.

The curved fault pattern north and northwest of Helper is part of a complex zone of accommodation between the Uncompahgre and Emery uplifts. The two uplifts are bounded by en echelon reverse fault zones (fig. 9) that require either a strike-slip zone or a complex curved fault zone between the two uplifts. Northwest-southeast motion of the Uncompahgre or Emery blocks would further complicate the structure in the intervening region. Along the curved faults north and northwest of Helper, high-angle reverse displacement (and local low-angle thrusting) occurred on east to northwesterly striking segments. Individual reverse faults pass into low-angle thrusts at their southeast ends; to the south, this fault geometry is replaced by the north-south thrust system described above. The curved faults in this accommodation zone appear to have been flattened and rotated toward the orientation of the north-south thrust system; such rotation is a further expression of shortening asso- ciated with northwesterly movement of the ancestral Uncompahgre uplift.

The fault pattern in and near the study area is consistent with a general northeast-southwest orientation for regional compression. Slight variations in the regional stress field during Pennsylvanian and Permian time could have produced alternating reverse and strike-slip motion on major pre-existing zones of weakness that trend about N. $60^{\circ} \mathrm{W}$. (For example, regional compression oriented between N. $45^{\circ}$ $\mathrm{E}$. and $\mathrm{N} .15^{\circ} \mathrm{E}$. could produce reverse displacement on the Uncompahgre fault and the northwesterly trending faults north of the Emery uplift; easterly excursions of regional compression direction would produce sinistral strike slip on the same faults.) The reflection data provide information only on dip-slip motion; there may have been a considerable strike-slip component of motion on some of the northwesterly striking subsurface faults in the study area.

Normal faults are also present, both parallel and orthogonal to the dominantly northwest trends of the reverse faults. Northeasterly striking normal faults are compatible with the northeast-southwest regional compression direction proposed above. The northwesterly striking normal faults may have developed in response to "post-Ancestral Rockies" (and pre-Kaibab) relaxation of the northeast-southwest compression. It is also possible that movement on some of these faults included a strike-slip component.

It is difficult to closely constrain the timing of movement on the late Paleozoic faults discussed here. The faults displace reflectors correlated with the Meramecian and Chesterian Doughnut Formation and do not offset reflectors correlated with the Leonardian Kaibab Limestone. In examples cited above, local unconformities (surfaces of truncation and onlap) were identified within the banded reflection zone in the Weber and Morgan Formations; these are surfaces of erosion and (or) nondeposition above fault blocks and are overlain by reflectors that are not affected by the late Paleozoic faulting. The P1 reflection is stratigraphically higher than almost all of these local unconformities and postdates most of the faults. If the Pl reflector marks the top of the Virgilian and Wolfcampian interbedded carbonate and clastic sequence, as suggested above, almost all of the late Paleozoic faulting would have to be pre-Wolfcampian. Relationships near fault $A$ on line EU-5, illustrated in plate 1, are the only examples of slightly younger Permian deformation cited here. Thus, the late Paleozoic faulting in the study area was certainly post-Chesterian and pre-Leonardian and probably pre-Wolfcampian in most cases. If, as suggested above, the faults are genetically tied to the displacement on the Uncompahgre fault, they were most active in Desmoinesian time because Desmoinesian sedimentation patterns strongly suggest that the Uncompahgre uplift was rising most rapidly at this time (Szabo and Wengerd, 1975; S.Y. Johnson, U.S. Geological Survey, written commun., 1990).

Kluth and Coney (1981) interpreted Ancestral Rockies orogenesis as the remote foreland expression of the Ouachita-Marathon orogeny, which was produced by collision between South America-Africa and a peninsular projection of the North American craton. Budnick (1986) proposed that the Ancestral Rockies were formed along the Wichita megashear in response to the collision of eastern 
North America with Africa (Alleghanian orogeny). These two models have different kinematic implications for the structures in and near the study area (Budnick, 1986). A right-lateral component of displacement on northwesterly striking faults would be consistent with the Kluth and Coney model, whereas a left-lateral component of displacement would be consistent with the Budnick model. Because the study area is small, the buried fault patterns cannot rule out either model; however, the fault patterns are most compatible with the model of Budnick (1986), which requires leftlateral shear along northwesterly trending faults and east- to northeast-directed compression. The relevant observations in the study area include the reverse component of movement on northwesterly striking faults and the local northsouth thrust belt that provides evidence for westward motion of the Uncompahgre block relative to the Paleozoic sedimentary rocks in the Price area. This study produced no evidence, however, that the Uncompahgre fault and the study area are part of a megashear along which 72-93 mi (120-150 $\mathrm{km}$ ) of left-lateral displacement occurred, as suggested by Budnick (1986). Instead, our analysis implies that strike-slip displacement on the Uncompahgre fault was probably less than $6 \mathrm{mi}(10 \mathrm{~km})$.

\section{REFERENCES CITED}

Baars, D.L., 1962, Permian system of the Colorado Plateau: American Association of Petroleum Geologists Bulletin, v. 46, p. 149-218.

Budnick, R.T., 1986, Left-lateral intraplate deformation along the Ancestral Rocky Mountains; implications for late Paleozoic plate motions: Tectonophysics, v. 132, p. 195-214.

Frahme, C.W., and Vaughn, E.B., 1983, Paleozoic geology and seismic stratigraphy of the northern Uncompahgre front, Grand County, Utah, in Lowell, J.D., ed., Rocky Mountain foreland basins and uplifts: Rocky Mountain Association of Geologists Guidebook, p. 201-211.

Franczyk, K.J., in press, Phanerozoic stratigraphic and time-stratigraphic cross sections along line $C-C^{\prime}$, Uinta and Piceance basin area, southern Uinta Mountains to northern Henry Mountains: U. S. Geological Survey Miscellaneous Investigations Series Map I-2184-C.
Heyman, O.G., 1983, Distribution and structural geometry of faults and folds along the northwestern Uncompahgre uplift, western Colorado and eastern Utah, in Averett, W.R., ed., Northern Paradox Basin-Uncompahgre uplift: Grand Junction Geological Society Guidebook, p. 45-57.

Hintze, L.F., 1988, Geologic history of Utah: Brigham Young University Geology Studies Special Publication 7, 202 p.

Hite, R.J., 1975, An unusual northeast-trending fracture zone and its relations to basement wrench faulting in northern Paradox Basin, Utah and Colorado: Four Corners Geological Society Field Conference, 8th, Canyonlands Guidebook, p. 217-223.

Huffman, A.C., Jr., and Taylor, D.J., 1989, San Juan Basin faulting-More than meets the eye [abs.]: American Association of Petroleum Geologists Bulletin, v. 73, p. 1161.

Kluth, C.F., and Coney, P.J., 1981, Plate tectonics of the Ancestral Rocky Mountains: Geology, v. 9, p. 10-15.

Loope, D.B., Sanderson, G.A., and Verville, G.J., 1990, Abandonment of the name "Elephant Canyon Formation" in southeastern Utah; physical and temporal implications: The Mountain Geologist, v. 27, p. 119-130.

Osmond, J.C., 1965, Geologic history of site of Uinta Basin, Utah: American Association of Petroleum Geologists Bulletin, v. 49, p. 1957-1973.

Stevenson, G.M., and Baars, D.L., 1986, The Paradox-A pullapart basin of Pennsylvanian age, in Peterson, J.A., ed., Paleotectonics and sedimentation in the Rocky Mountain region, U.S.: American Association of Petroleum Geologists Memoir 41, p. 513-539.

Stone, D.S., 1977, Tectonic history of the Uncompahgre uplift, in Veal, H.K., ed., Exploration frontiers of the central and southern Rockies: Rocky Mountain Association of Geologists Field Conference, 1977, Guidebook, p. 23-30.

Szabo, E., and Wengerd, S.A., 1975, Stratigraphy and tectogenesis of the Paradox Basin: Four Corners Geological Society Field Conference, 8th, Canyonlands Guidebook, p. 193-211.

Waechter, N.B., and Johnson, W.B., 1985, Seismic interpretation in the Piceance Basin, northwest Colorado, in Gries, R.R., and Dyer, R.C., eds., Seismic exploration of the Rocky Mountain region: Rocky Mountain Association of Geologists and Denver Geophysical Society, p. 247-258.

White, M.A., and Jacobson, M.I., 1983, Structures associated with the southwest margin of the ancestral Uncompahgre uplift, in Averett, W.R., ed., Northern Paradox Basin-Uncompahgre uplift: Grand Junction Geological Society Guidebook, p. 33-39. 


$$
-\infty .+\cdots
$$


.............. 